Brit. J. industr. Med., 1952, 9, 275.

\title{
SOME EFFECTS OF PAID SICK LEAVE ON SICKNESS ABSENCE
}

\author{
BY \\ R. A. DENERLEY \\ From the Medical Research Council Group for Research in Industrial Psychology
}

(RECEIVED FOR PUBLICATION MAY 27, 1952)

In recent years the tendency to give greater economic protection to industrial workers has led to the introduction of many sickness benefit schemes. This article considers the effects on sickness absence of two schemes for the payment of wages during illness and injury.

Company $\mathbf{Z}$ was a large organization controlling many factories in different parts of the country. In September, 1948, workers with at least six months' service were granted sick leave with full pay for a maximum of 13 weeks in any 12 months, and those with at least five years' service were granted an additional period of 13 weeks on half pay. "Full pay" was defined as ordinary time rate minus the amount of National Insurance benefit to which the worker was entitled. Medical certificates were required after three days of sickness or injury, and subsequently at weekly intervals. Payment was not made for the first three days' absence unless the incapacity lasted for at least five working days.

Company $\mathrm{V}$, another large industrial organization with many factories throughout the country, had operated since 1928 an establishment scheme giving " to workers selected on grounds of individual merit a status and a form of security approximating to that of staff". An established worker was guaranteed a weekly wage at least equivalent to his ordinary time rate, and if sick or injured, received this amount (less National Insurance benefits) for a maximum of 26 weeks in any calendar year. He was also entitled to four weeks' notice of the termination of his employment, and, in addition, could be granted leave of absence on full pay at the discretion of the management. All workers who had completed three years' service and were at least 24 years of age were eligible for establishment but not more than half of them could be in the established grade at any one time. Selection depended upon the assessment of certain personal qualities, and each eligible worker was rated by his local management every six months. Various methods were used in different parts of the organization, but the qualities assessed usually included willingness, industry, initiative, reliability, example to others, ability, and adaptability. Very little weighting was given to length of service, but the worker's timekeeping record was considered. It was laid down that absence due to certified sickness should not affect a worker's chances of being established. An established worker was paid for all absence of less than three days' duration provided that a satisfactory explanation was given ; medical certificates were required on the third day of absence and subsequently at weekly intervals. Complementary to the establishment scheme, all non-established men who had completed three years' service qualified automatically for sick pay at the rate of 12s. 6d. per week for a maximum of 13 weeks in any year.

\section{Absence in Company $Z$}

Company Z employed over 40,000 workers, almost $90 \%$ of whom were men. The percentages of working days lost due to certified sickness (including injury) during the 12 months before and after the introduction of sick leave with pay are shown in Fig. 1. Absence curves are also included for all male employees of Company V, the 20,000 established workers being shown separately from the 41,000 non-established workers. The figures on which the graphs are based are given in Table A of the Appendix.

Before Company $Z$ introduced sick leave with pay absence was closely similar to that among nonestablished workers in Company V. As soon as the scheme was introduced, there was an immediate and spectacular increase in absence, and during the following year it was at a level comparable with that of established workers in Company V. Both curves for Company $\mathrm{V}$ followed the usual seasonal 


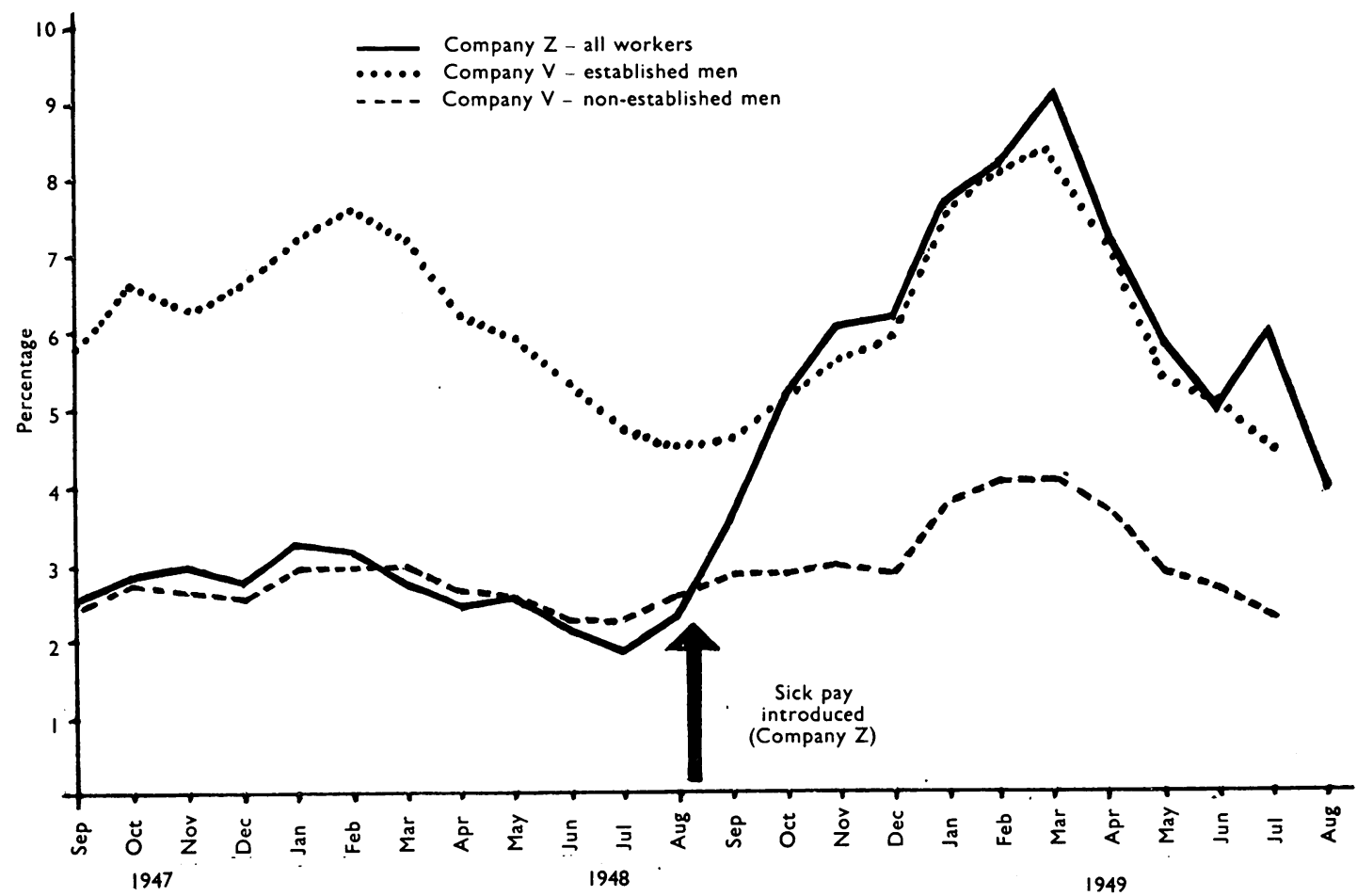

FIG. 1.-Sickness absence before and after the introduction of paid sick leave (no. of shifts lost as percentage of no. of shifts possible).

trends, and during the winter of 1948-49 absence was about $1 \%$ higher than in the previous year. As there was no radical change in the composition of Company Z's labour force, it seems reasonable to expect that it, too, would have shown a similar small increase if the sick pay scheme had not been introduced. Absence was, however, more than doubled compared with the previous year, and it seems certain that most of this increase was attributable to sick leave with pay. Some reasons for this are discussed later in this paper.

In Company $\mathbf{Z}$ it was also possible to demonstrate the influence which financial incentives can exert on sickness absence. In each of two factories $(X$ and Y) there was a department of about 150 men working under closely similar conditions. The factories were in different parts of the country, but the two departments had started work in 1946 and they were practically identical as regards lay-out, equipment, and production methods. The men in Department $Y$ of Factory $Y$ were, however, older and physically less fit than those in Department $X$ of Factory X. Both departments were paid on group output bonus systems which were similar in principle, but since 1947 the men in Department Y had been dissatisfied with their earnings and had claimed that the bonus standards were too tight. In consequence there was an atmosphere of mutual distrust between management and workers, and relations were not so good as in Department X. It was not, therefore, surprising that during 1947-48 the men in Department $Y$ usually had more absence than those in Department $\mathrm{X}$, and, in particular, they were more prone to take occasional days off from work.*

Both departments were scheduled to cease production at the end of 1948, and the men were to be offered jobs in other parts of the factories. The circumstances under which the departments closed were, however, quite different. The men in Department $\mathrm{X}$ were told of the approaching end of production in November, and during the following weeks some of the regular workers were transferred to a new department. They were replaced by trainees who could not be expected to have much enthusiasm for a job which was drawing to its close. In contrast to this the men in Department $Y$

* During the 12 months ending September 4, 1948, absence due to all causes averaged $7.2 \%$ in Department $Y$ as compared with $5.8 \%$ in Department $\mathrm{X}$. 
were warned in August that production would cease at the end of the year, and they were given the opportunity to take over the uncompleted contracts of other factories. An assurance was given by the management that the bonus scheme would not be altered however high the earnings rose. The men in both departments knew that when production stopped they would be transferred to other work with no chance of earning bonuses for several weeks. Accordingly the men in Department $Y$ decided to go all out while the going was good, and the output bonus rose to $£ 315 \mathrm{~s}$. per man per week, which was about twice that being received by the men in Department X. Fig. 2 shows the weekly absence in these two departments. during the latter half of 1948 ; comparable data are also included for all men employed in Factory Y. Reasons for absence having been classified less accurately in Factory $\mathrm{Y}$ than in Factory $\mathrm{X}$, it has been necessary to compare figures of absence due to all causes*. The data on which Fig. 2 is based are given in Table B of the Appendix. throughout the first quarter of 1949 an average of one man in five was away from work. But the figures for Department $Y$ did not show any corresponding increase, and absence at the end of the year was the same as it had been in September when sick pay was introduced. It would seem that for these men any temptation to take advantage of sick leave with pay was neutralized by the lure of high earnings. During this period minor ailments were ignored and some men came to work when they appeared unfit to do so. Typical comments from workers who were interviewed were :-

"We're getting a good bonus now, but I doubt whether the men can keep this pace going. It's too much for some of them, but they want the money."

"Some of the men aren't fit to be at work, but they know what's in store for them, and they're taking their chance whilst they can."

The financial incentive and the pace of work were abnormally high, and neither could have been maintained for long. In fact there were signs of a sharp increase in absence during the last week of December when work was fading out. The men
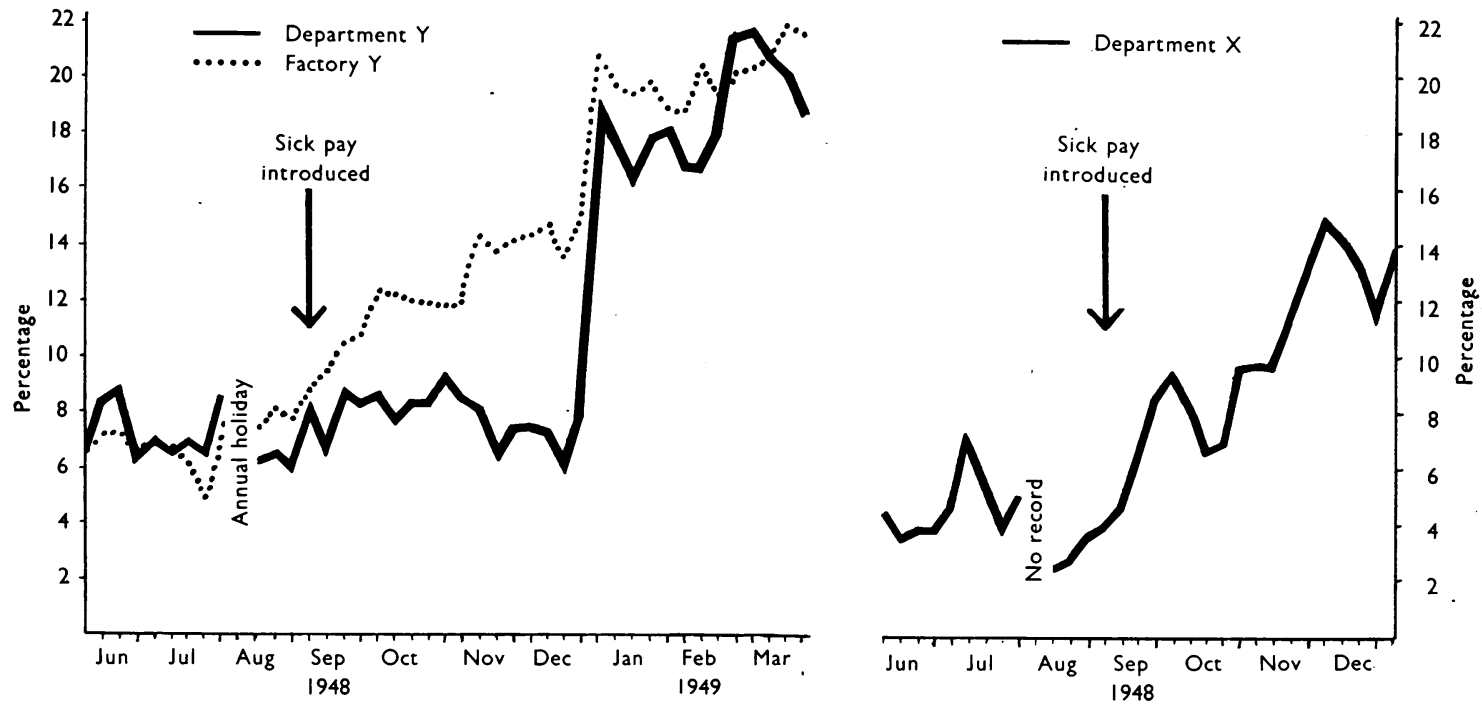

Fig. 2.-Weekly absence due to all causes (no. of shifts lost as percentage of no. of shifts possible).

In Department $\mathrm{X}$ the introduction of sick pay was immediately followed by a rapid increase in absence. From November onwards, when it was known that the department was to close, absence due to all causes averaged about $13 \%$. In Factory $Y$ there was also an immediate and spectacular rise in the absence rate. By the end of the year absence was twice what it had been in December, 1947, and * A more detailed explanation is given on page 279 . were transferred to other departments at the beginning of January, and their absence records were obtained for the following three months. It will be observed that when the spur of exceptionally high earnings was removed the rate of absence immediately climbed to the high level which existed in the rest of Factory $Y$. In these circumstances, it seems likely that the need to earn as much as possible before the department closed had kept 
these men at work when they might otherwise have stayed away. The fact that they did not succumb to the temptation of sick leave with pay suggests the extent to which minor ailments can temporarily be resisted when the financial incentive is sufficiently strong.

\section{Absence in Company $\mathrm{V}$}

Further reference to Fig. 1 shows that between 1947 and 1949 sickness absence among established men in Company $\mathrm{V}$ was roughly double that among non-established. Sickness has always been higher among established workers, and even during the pre-war years when there was considerable unemployment and hence less security, it was often $50 \%$ greater. Shortly after the war the gap between the figures widened, absence having increased more among the established men than among the non-established. In comparing these figures it is important to take into account the effects of age on sickness absence, as the established workers were on the average about 10 years older than the non-established.

In one of Company V's factories, Factory C, where about 1,000 established and 2,500 nonestablished men were employed, an analysis was made of sickness absence during the period from January to June, 1948. The figures for each age group are shown in Table 1. ment of wages during sickness enabled workers to stay at home until fully recuperated so that some quite justifiable extension of sickness absence could be expected*. It also seems reasonable to assume that in some cases doctors prescribed treatment or convalescence which were only feasible for workers whose earnings were protected. It is probable, too, that some workers took sick leave when they might otherwise have remained at work. These consequences of sick leave with pay would result in a higher absence rate, but the ensuing benefits to health should help to reduce the risk of sickness in later years.

Table 1 shows that the greatest difference in sickness absence between the established and nonestablished workers was in the 25 to 34 age group, and the least difference was between workers above the age of 55 . If the non-established men were unable to stay away from work when sickness would have justified them doing so, or if they returned to work before they were fit, they might be expected to incur more frequent or more prolonged absence later in their working lives. Although the percentage differences in sickness absences do not show a consistent trend (see Table 1), the small difference between workers over the age of 55 may be partly due to the fact that the payment of wages during previous sickness had to some extent

TABLE 1

RELATION BETWEEN AGE AND SICKNESS ABSENCE IN FACTORY C JANUARY TO JUNE, 1948

\begin{tabular}{|c|c|c|c|c|c|c|c|c|c|}
\hline \multirow{3}{*}{ Age Group } & \multicolumn{4}{|c|}{ Established Men } & \multicolumn{4}{|c|}{ Non-established Men } & \multirow{3}{*}{$\begin{array}{l}\text { Percentage } \\
\text { Difference }\end{array}$} \\
\hline & \multirow{2}{*}{$\begin{array}{l}\text { Number } \\
\text { of Men }\end{array}$} & \multirow{2}{*}{$\begin{array}{l}\text { Shifts } \\
\text { Possible }\end{array}$} & \multicolumn{2}{|c|}{ Shifts Lost } & \multirow{2}{*}{$\begin{array}{l}\text { Number } \\
\text { of Men }\end{array}$} & \multirow{2}{*}{$\begin{array}{c}\text { Shifts } \\
\text { Possible }\end{array}$} & \multicolumn{2}{|c|}{ Shifts Lost } & \\
\hline & & & Number & $\%$ & & & Number & $\%$ & \\
\hline $\begin{array}{l}\text { Under } 25 \\
25 \text { to } 34 \\
35 \text { to } 44 \\
45 \text { to } 54 \\
55 \text { and over }\end{array}$ & $\begin{array}{l}\overline{127} \\
355 \\
392 \\
209\end{array}$ & $\begin{array}{l}1 \overline{6,129} \\
45,085 \\
49,784 \\
26,513\end{array}$ & $\begin{array}{r}\overline{560} \\
1,417 \\
2,072 \\
1,440\end{array}$ & $\begin{array}{l}3.47 \\
3 \cdot 14 \\
4 \cdot 16 \\
5 \cdot 43\end{array}$ & $\begin{array}{l}235 \\
664 \\
652 \\
552 \\
391\end{array}$ & $\begin{array}{l}29,845 \\
84,328 \\
82,804 \\
70,104 \\
49,657\end{array}$ & $\begin{array}{r}543 \\
1,527 \\
1,889 \\
2,048 \\
2,632\end{array}$ & $\begin{array}{l}1 \cdot 82 \\
1 \cdot 81 \\
2 \cdot 28 \\
2 \cdot 92 \\
5 \cdot 30\end{array}$ & $\begin{array}{l}\overline{1 \cdot 66} \\
0.86 \\
1 \cdot 24 \\
0.13\end{array}$ \\
\hline
\end{tabular}

In both groups sickness absence tended to increase with age*. Hence the established workers in Factory $\mathrm{C}$ could be expected, because of their higher average age, to have a higher absence rate than the non-established workers. Although absence figures according to age were not available for Company $\mathrm{V}$ as a whole, it seemed reasonable to assume that, as in Factory $\mathrm{C}$, the higher average age of the established men was one reason for their greater absence.

But, in each case when men of the same age were compared, the established men had more absence than the non-established (see Table 1). The pay-

\footnotetext{
* A similar trend was shown by absence records obtained from
} another large organization. protected the health of the established workers. It does however seem certain that there was some deliberate abuse of sick leave with pay. Some evidence in this connexion was provided by the results of an attitude survey in Factory $C$, where, amongst other questions, each worker was asked, "Are you in the established grade ?" and, "What do you think of it?" About $15 \%$ of both the established and the non-established men said that the scheme was abused by some workers. The

* During the enquiries in Factory C, 22 established and 34 nonestablished men resumed work after periods of certified sickness ; 18 of the former and 20 of the latter returned on the first day of the week, and not one person restarted after the third day of the week. Although this evidence is scanty, it would seem that some doctors tend to sign off patients so that they can resume work at the beginning of a week. 
former tended to point out that " only a few workers take advantage of the scheme", whereas the latter more often referred in general terms to its abuse. In one large department where 35 supervisors were interviewed, 31 of them said that there was some abuse of the scheme. The absence rates in Factory $\mathrm{C}$ at this period compared favourably with absence in Company $\mathrm{V}$ as a whole. Analysis of records maintained by Factory $C$ indicated that absence among established workers tended to be both more frequent and more prolonged than amongst nonestablished workers. Referring again to Table 1 it will be observed that established men below the age of 35 had rather more absence than those between the ages of 35 and 44 . A higher proportion of the younger age group would have been recently established and there are grounds for surmising that newly promoted workers were especially prone to take advantage of the scheme. In discussing this aspect of establishment, one workers' representative said, "We've got some fellows who never had a day's illness in their lives until they were promoted". Thus, some abuse of the scheme existed even though the selection of workers was based on qualities such as "reliability" and " example to others".

\section{Discussion}

In both these companies the granting of sick leave with pay to workers whose earnings had not previously been protected was followed by an increase in sickness absence. Company $Z$ introduced sick pay only two months after the National Health Service started, and the combination of these two schemes radically altered the financial position of workers during sickness, especially of those with families to support. Workers who had been unable to afford operations or long courses of treatment were likely to take an early opportunity of having them under the National Health Service, particularly as Company $\mathrm{Z}$ guaranteed to pay their full time-rate while they were away from work. It seems probable that the rapid increase in sickness absence experienced by Company $Z$ was partly due to the fact that the sick pay scheme was introduced so soon after the National Health Service.

Absence in Department $Y$ demonstrated that the temptation to take advantage of sick leave with pay could be resisted when the financial incentive was exceptionally strong. It also seems reasonable to assume that temptation to malinger would be particularly great when the worker was financially better off at home than at work. In this respect it should be noted that during sickness a worker paid no National Insurance contribution and no income tax on his National Insurance sickness benefit. The compulsory deductions from wages might, therefore, be very much less than those usually paid. In addition, some workers received sickness benefits from friendly societies to which they voluntarily contributed.

The greater incentive to obtain medical certificates led in some factories to more accurate classification of the reasons for absence. In Factory $\mathrm{Y}$ total absence had averaged $7 \cdot 2 \%$ during the year before sick pay was introduced, and of this $3.2 \%$ had been classified as certified sickness and $3.3 \%$ as absence without leave. In the following year absence without leave dropped to $2.0 \%$ and sickness absence rose to $12.3 \%$, representing $81 \%$ of the total absence as compared with only $44 \%$ formerly. There had previously been no systematic enforcement of the rule requiring medical certificates to be produced after three days of absence, and there can be no doubt that some cases of genuine sickness had been recorded as absence without leave. Hence, a comparison of the recorded sickness rates for these two years would exaggerate the increase attributable to sick leave with pay. By comparison, absence had been more efficiently classified in Factory $\mathrm{X}$, and during these two years absence without leave showed no significant reduction.

In Company $\mathrm{Z}$ workers were not paid for the first three days' sickness unless their absence lasted for at least five working days. There was thus a strong temptation to prolong short illnesses. Established workers in Company $\mathrm{V}$ were paid for all absence and it seems probable that this encouragement to obtain early treatment may have prevented some longer or more serious illnesses and reduced the risk of spreading infection in the factory. Both schemes removed much of the financial worry and anxiety which many workers had previously associated with sickness absence. Typical comments by men interviewed in Factory C were :-

"It gives a sense of security during illness and removes the nagging fear about your family."

"It gives a man security-a month's notice, and his wages when sick. Some men used to start back at work before they were really better."

On the other hand, although most workers appreciated the reduced economic pressure to resume work, there were others for whom the inclination to work was also lessened. Some men stayed away from work unnecessarily, and others prolonged minor ailments for the purpose of obtaining sick pay. In Company $\mathrm{Z}$ several men who had obtained medical certificates from their doctors were found to be drawing sick pay 
when working temporarily for other employers.

This article has been confined to the effects on sickness absence of two schemes for the payment of wages during illness. It seems probable that, among other important effects, these schemes may give rise to increased feelings of satisfaction and loyalty to the firm, but such considerations are not within the scope of this article.

\section{Summary}

In Company $\mathrm{Z}$ sickness absence rose from $2 \cdot 6 \%$ in the year before the introduction of sick pay to $6.1 \%$ in the year after it was introduced (Table A). In one department, where bonus earnings were exceptionally high, the introduction of sick pay had no effect on sickness absence until earnings were substantially reduced (Table B).

In Company $\mathrm{V}$ sickness absence for established men was roughly double that for non-established men (Table A). Some of this increase was attributable to the higher average age of the established men, but when age was made constant, the difference in sickness absence was still appreciable (Table 1). There was evidence that a few established workers abused the scheme, particularly those who had only recently begun to benefit from it.

Payment of wages during illness reduced the workers' fear of sickness absence, and may have helped to prevent further sickness by providing the opportunity to recuperate fully before resuming work. 


\section{A P P E N D I X}

TABLE A PERCENTAGE OF SHIFTS LOST DUE TO CERTIFIED SICKNESS AND INJURY

\begin{tabular}{|c|c|c|c|c|c|c|c|c|c|}
\hline & \multirow{2}{*}{ Ionth } & \multirow{2}{*}{$\begin{array}{c}\text { Company } \\
\mathrm{Z}\end{array}$} & \multicolumn{2}{|c|}{ Company V } & \multirow{2}{*}{\multicolumn{2}{|c|}{ Month }} & \multirow{2}{*}{$\begin{array}{c}\text { Company } \\
\mathrm{Z}\end{array}$} & \multicolumn{2}{|c|}{ Company V } \\
\hline & & & Established & $\begin{array}{c}\text { Non- } \\
\text { established }\end{array}$ & & & & Established & $\begin{array}{c}\text { Non- } \\
\text { established }\end{array}$ \\
\hline 1948 & $\begin{array}{l}\text { September } \\
\text { October } \\
\text { November } \\
\text { December } \\
\text { January } \\
\text { February } \\
\text { March } \\
\text { April } \\
\text { May } \\
\text { June } \\
\text { July } \\
\text { August }\end{array}$ & $\begin{array}{l}2 \cdot 5 \\
2 \cdot 8 \\
2 \cdot 9 \\
2 \cdot 7 \\
3 \cdot 2 \\
3 \cdot 1 \\
2 \cdot 7 \\
2 \cdot 4 \\
2 \cdot 5 \\
2 \cdot 1 \\
1 \cdot 8 \\
2 \cdot 2\end{array}$ & $\begin{array}{l}5 \cdot 8 \\
6 \cdot 6 \\
6 \cdot 3 \\
6 \cdot 6 \\
7 \cdot 2 \\
7 \cdot 6 \\
7 \cdot 2 \\
6 \cdot 2 \\
5 \cdot 9 \\
5 \cdot 3 \\
4 \cdot 7 \\
4 \cdot 5\end{array}$ & $\begin{array}{l}2 \cdot 4 \\
2 \cdot 7 \\
2 \cdot 6 \\
2 \cdot 5 \\
2 \cdot 9 \\
2 \cdot 9 \\
2 \cdot 9 \\
2 \cdot 6 \\
2 \cdot 5 \\
2 \cdot 2 \\
2 \cdot 2 \\
2 \cdot 5 \\
\end{array}$ & 1948 & $\begin{array}{l}\text { September } \\
\text { October } \\
\text { November } \\
\text { December } \\
\text { January } \\
\text { February } \\
\text { March } \\
\text { April } \\
\text { May } \\
\text { June } \\
\text { July } \\
\text { August }\end{array}$ & $\begin{array}{l}3 \cdot 5 \\
5 \cdot 1 \\
6 \cdot 0 \\
6 \cdot 1 \\
7 \cdot 6 \\
8 \cdot 1 \\
9 \cdot 0 \\
7 \cdot 1 \\
5 \cdot 8 \\
4 \cdot 9 \\
5 \cdot 9 \\
3 \cdot 9\end{array}$ & $\begin{array}{l}4 \cdot 6 \\
5 \cdot 1 \\
5 \cdot 6 \\
5 \cdot 9 \\
7 \cdot 5 \\
8 \cdot 1 \\
8 \cdot 3 \\
7 \cdot 1 \\
5 \cdot 3 \\
5 \cdot 0 \\
4 \cdot 4 \text { No }\end{array}$ & $\begin{array}{l}2 \cdot 8 \\
2 \cdot 8 \\
2 \cdot 9 \\
2 \cdot 8 \\
3 \cdot 7 \\
4 \cdot 0 \\
4 \cdot 0 \\
3 \cdot 6 \\
2 \cdot 8 \\
2 \cdot 6 \\
2 \cdot 6 \\
\text { cord }\end{array}$ \\
\hline \multicolumn{2}{|c|}{ Average } & $2 \cdot 6$ & $6 \cdot 2$ & 2.6 & \multicolumn{2}{|c|}{ Average } & $6 \cdot 1$ & $6 \cdot 1$ & $3 \cdot 1$ \\
\hline
\end{tabular}

TABLE B

WEEKLY ABSENCE DUE TO ALL CAUSES

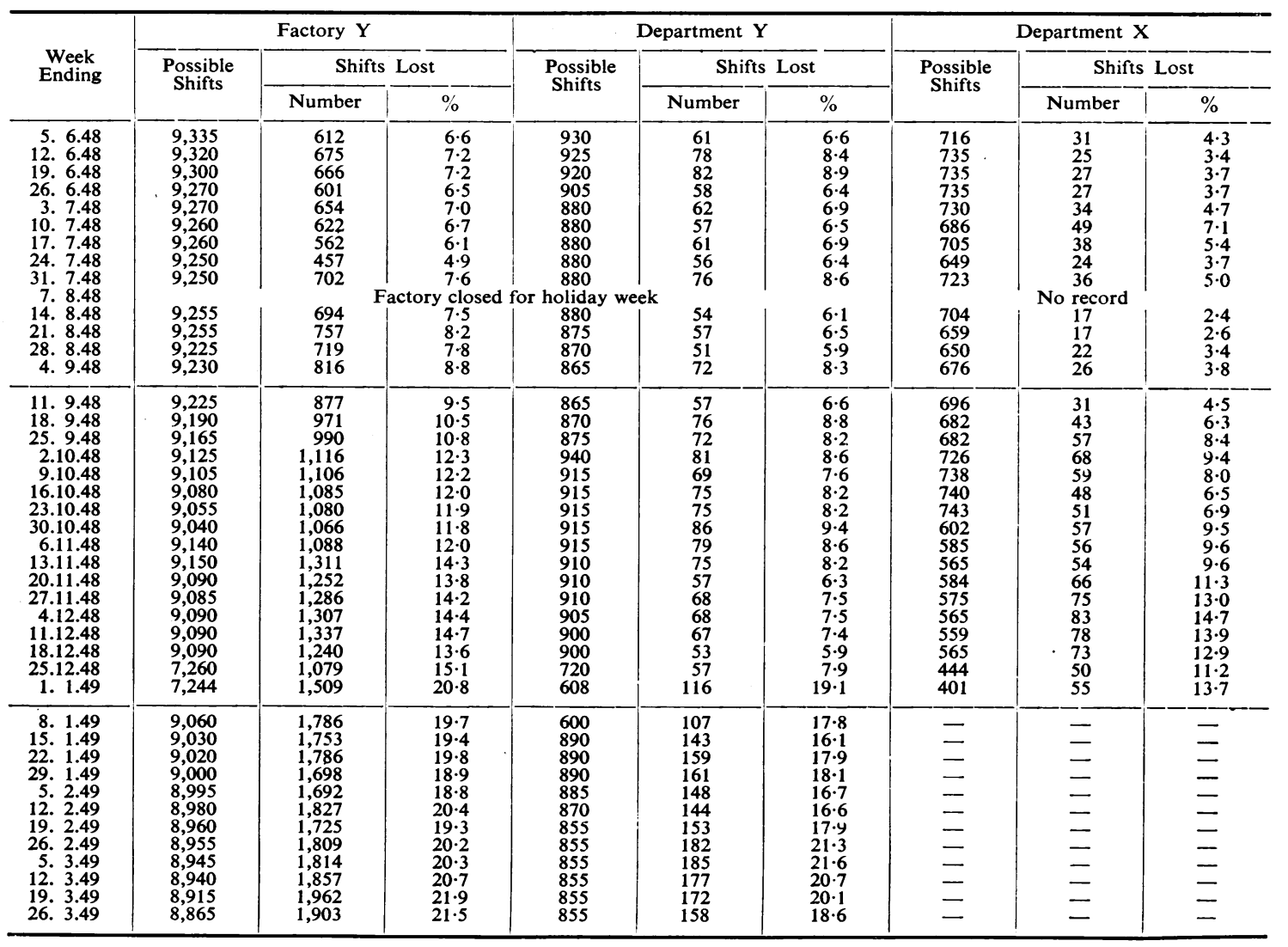

